\section{Developing a Sharī ah-compliant equity-based crowdfunding framework for entrepreneurship development in Malaysia}

\author{
Maya Puspa Rahman, Mohamed Asmy Mohd Thas Thaker and \\ Jarita Duasa \\ Faculty of Economics and Management Sciences,
} International Islamic University Malaysia, Kuala Lumpur, Malaysia

Crowdfunding framework

\begin{abstract}
Purpose - Crowdfunding has become one of the preferred mechanisms to raise funds by startups and small entrepreneurs. As such, this paper aims to develop an appropriate framework for Sharí' ah-compliant equitybased crowdfunding (SEC) for entrepreneurship development in Malaysia.
\end{abstract}

Design/methodology/approach - The research begins by analyzing the intention of 200 entrepreneurs in Kuala Lumpur and Selangor regarding the use of crowdfunding to raise capital. The analysis is based on the theory of reasoned action (TRA), which is also associated with the technology acceptance model (TAM) and is effected by using structural equation modeling (SEM).

Findings - The entrepreneurs agree on the ease of use of crowdfunding in raising capital, although it appeared that they are quite reluctant to share their business ideas online. Subsequently, an SEC framework is proposed, to further enhance entrepreneurship development in Malaysia particularly in meeting the need for raising funds in line with Sharī ah (Islamic law) principles.

Practical implications - This paper aims to contribute more to the development of a blueprint for an SEC platform for market players and regulators in Malaysia.

Social implications - This paper also aims to highlight the growing needs of entrepreneurs, particularly in Malaysia to have a Shari' ah-compliant alternative to raise funds via crowdfunding.

Originality/value - This paper makes two main contributions. First, it provides evidence on Malaysian entrepreneurs' intention to use crowdfunding for fundraising through TAM and SEM analysis. Second, it proposes an SEC framework for the development of entrepreneurs in Malaysia.

Keywords Structural equation modeling (SEM), Malaysian entrepreneurship, Sharī'ah-compliant equity-based crowdfunding (SEC), Theory of reasoned action (TRA)

Paper type Research paper

(C) Maya Puspa Rahman, Mohamed Asmy Mohd Thas Thaker and Jarita Duasa. Published in ISRA International Journal of Islamic Finance. Published by Emerald Publishing Limited. This article is published under the Creative Commons Attribution (CC BY 4.0) licence. Anyone may reproduce, distribute, translate and create derivative works of this article (for both commercial and noncommercial purposes), subject to full attribution to the original publication and authors. The full terms of this licence may be seen at http://creativecommons.org/licences/by/4.0/legalcode

This research is funded by the Fundamental Research Grant Scheme 2016 (FRGS16-062-0561), Ministry of Higher Education Malaysia.
Received 25 July 2018 Revised 13 November 2018

5 April 2019

8 June 2020

20 June 2020

Accepted 20 June 2020 


\section{Introduction}

Crowdfunding is certainly not something new in the global capital markets. Since 2012, crowdfunding has become a trendy fundraising mechanism for entrepreneurs globally. Popular crowdfunding platforms such as Kickstarter and Indiegogo exist in the United States of America (USA). Malaysia is also proud to have its own local crowdfunding platforms such as pitchIN, mystartr and Ata Plus, to name a few. In 2015, Malaysia made history by being the first country to legalize equity crowdfunding in Southeast Asia, issuing six licenses for equity crowdfunding (ECF) platforms to operate in the country (Rahman et al., 2016). Subsequently, six peer-to-peer (P2P) crowdfunding licenses were issued in November 2016, which have increased to 11 as of March 2020 (Securities Commission Malaysia, 2020, (SC)). Collectively, P2P has successfully raised RM 739m from 9,989 campaigns while ECF has raised RM 86m from 89 campaigns (SC, 2020).

It is essential to appreciate that transparency is one of the many reasons for the ready acceptance of crowdfunding by both entrepreneurs and investors. Entrepreneurs seeking funds through the crowdfunding mechanism must disclose all related information in a short video, which is then uploaded on a specific crowdfunding platform. This video informs investors about the company's background, the purpose of the fundraising, the fund target level and the rewards (or returns) that can be obtained. The rewards may be in monetary or non-monetary form. For example, some projects are philanthropically driven with the purpose of relieving specific issues among certain communities; hence, supporting such plans provides pure satisfaction and inner happiness to the investors. This is known as donation-based crowdfunding. On the other hand, reward-based crowdfunding offers material incentives to investors, generally in the form of items that are related to the cause of the fundraising exercise.

Another type of crowdfunding is known as P2P lending, which operates similarly to conventional lending, yielding interest as the return to the investors. Equity-based crowdfunding is another type whereby investors obtain a percentage of ownership of a company in proportion to the amount invested. The entrepreneurs raising funds through equity-based crowdfunding must convince investors that the company will grow in value over time and provide them with options to exit the investment and obtain a capital gain in the future. In addition, entrepreneurs must also be able to induce investors with the possibility of a good income stream (in the form of a dividend) over the holding period, similar to an investment in shares in the equity market. On this note, it is believed that this mechanism would encourage Muslim entrepreneurs to take part in such investments, especially with the potential development of a Sharī'ah-compliant equity crowdfunding (SEC) framework, which would allow them to grow hand-in-hand with the dedicated investors and benefit from economic prosperity.

This paper aims to shed light on how Muslim entrepreneurs can benefit from equity crowdfunding and introduces the concept of an SEC framework. Even though it is known that several crowdfunding platforms - such as Ethis and Kapital Boost, to name a few - are using the Islamic concepts for fundraising, a fundamental study on the acceptance of these models in the Malaysian market has yet to be undertaken. This study attempts to fill in this research gap. Accordingly, this study begins by gauging entrepreneurs' general understanding and acceptance of crowdfunding by conducting a survey in the Klang Valley area and analyzing the data based on the theory of reasoned action (TRA).

This paper is organised as follows. The next section highlights the development of crowdfunding and pertinent issues associated with it. This is followed by a presentation of the survey analysis, measuring the entrepreneurs' intention to use crowdfunding in Malaysia through structural equation modelling (SEM). Subsequently, the conceptual 
framework of SEC for Malaysia is discussed. The last section concludes with some recommendations for future research.

\section{Crowdfunding development and current issues}

Raising sufficient capital has been one of the main challenges for businesses, especially start-ups. After the 2008 financial crisis, financing was further tightened, leaving minimal options for entrepreneurs and early-stage enterprises to raise funds. Nonetheless, with the advancement of technology, entrepreneurs have become more independent and innovative in raising capital, extending what was known as traditional financing by friends and family to the most significant new means of fundraising in the world, known as crowdfunding. Crowdfunding has become a practical tool to overcome the funding gap and risk implications faced by financial institutions.

The World Bank (2013) defines crowdfunding as an internet-enabled way for businesses or other organizations to raise money in the form of donations or investments from multiple individuals. Crowdfunding platforms circumvent the tedious process of raising funds from the capital market or loans from financial institutions by bridging the gap between entrepreneurs and the mass public. Kickstarter and Indiegogo are, perhaps, the most prominent examples of such platforms; however, to date, there are more than 1,000 crowdfunding platforms globally, concentrated mainly in North America, Europe and Oceanic and Asian countries (Fundly, 2020).

The recent introduction of equity-based crowdfunding in Malaysia provides more alternates for Muslim entrepreneurs to raise funds. It is believed that equity-based crowdfunding represents a significant opportunity to deliver the essential expectations from Islamic finance by combining the benefits of social development and investment opportunities for a wide range of entrepreneurs and investors. Sharīah-compliant crowdfunding is seen to further provide an opportunity for entrepreneurship development, especially to those focusing on offering Shari' ah-compliant goods and services in Malaysia. Before discussing the Sharīah perspective on the current crowdfunding mechanisms, it would be beneficial to highlight the growth of the crowdfunding industry, thus far.

\section{The growth of the crowdfunding industry}

Crowdfunding has become the preferred mechanism for small businesses and start-ups, in particular, to raise funds because of its swift and easy process as compared to seeking funds from banks and financial institutions. The global funding volume is estimated to be over US $\$ 34$ bn, which has grown by more than 1,000\%, as its inception in 2012. It is estimated that it will further triple by 2025 (Hoegen et al., 2017; Statista, 2020).

According to Massolution (2015), a total of 1,250 crowdfunding platforms are in operation globally, with more than $70 \%$ of them based in North America and Europe. It was reported that over the past five years more than $40 \%$ of the funding volume was raised by business and entrepreneurial ventures. Other recipient categories include real estate $(6.25 \%)$, film and performing arts $(12.3 \%)$ and social causes $(19 \%)$. With the growing interest in crowdfunding, researchers have been conducting studies on its various aspects. One interesting subject of study is what motivates entrepreneurs to participate in crowdfunding. Ferrary and Granovetter (2009) highlight that from the entrepreneurs' perspective, apart from addressing immediate capital needs, crowdfunding can be used - and indeed has been used - as a means of demonstrating demand, which, in turn, can lead to obtaining funding from traditional sources, usually via venture capital or angel investors. In addition to that, crowdfunding has also been used as a marketing tool to generate interest in new projects or products. Another study by Gerber et al. $(2012$, p. 8) argues that creators "are motivated to Crowdfunding
framework 
participate to raise funds, receive validation, connect with others, replicate successful experiences of others and expand awareness of work through social media".

Valanciene and Jegeleviciute (2013) analyzed crowdfunding and presented a strengths, weaknesses, opportunities, threats (SWOT) analysis as described in Table I.

This SWOT analysis is essential to highlight the strengths and opportunities of crowdfunding that can benefit investors and entrepreneurs, as well as to identify any challenges that need to be addressed by the authorities. For example, the European Union has regarded crowdfunding as one of the mechanisms to foster entrepreneurship in its European 2020 strategy, while in the USA, legislation has been enacted on crowdfunding (Valanciene and Jegeleviciute, 2013).

On another development front, SC Malaysia approved six P2P crowdfunding platform operators in November 2016 in its effort to widen and provide more funding options for small and medium entrepreneurs. This makes Malaysia the first country in the ASEAN region to regulate $\mathrm{P} 2 \mathrm{P}$. On this note, an outstanding 2,505 P2P crowdfunding campaigns have been successful with RM 212.7m raised (SC, 2020).

Even though Sharī'ah-compliant crowdfunding is still new, several studies have raised essential points about it. Alonso (2015), for example, undertook a case study on an SEC platform in Egypt known as Shekra that has developed a business model based on positive values and social accountability. Interestingly, raising funds through Shekra is done in a Sharī ah-compliant manner and entrepreneurs should not use the raised funds for Sharī'ah non-compliant business activities. Legally, investors take a specific equity stake in the project, which will gain return based on profit-and-loss sharing. To ensure long-term commitment, Shekra also acts as a partner and takes an equity stake once funds start to flow in.

Wahjono and Marina (2015) highlight the suitability of an SEC framework being used in countries with Muslim-majority populations such as Indonesia. Some of the suitable contracts mentioned are mushärakah (profit-and-loss sharing) and qard hasan (interest-free loan). In light of this, Achsien and Purnamasari (2016) deliberated on possible rules to

Table I.

SWOT analysis on crowdfunding
Strengths

- Accessibility of capital

- Benefits to communities

- Rights to make a company's decisions stay in the hands of entrepreneurs

- A chance to test the marketability

Opportunities

- Existence of niches

- Positive effects are expected for the economy

- Information society

Source: Valanciene and Jegeleviciute (2013)
Weaknesses

- Possibility of ideas being stolen, weaker investor protection and potential for fraud

- Investors might lack advice as crowdfunding is exceptionally internet-based

- Administrative and accounting challenges

Threats

- Unsuitable legal restrictions arise

- Risky nature of small business 
incorporate an SEC framework, which was expected to encourage the growth of Islamic finance in Indonesia. On this note, EthisCrowd, founded in 2014, is in the forefront as it is the first Indonesia-focused real estate crowdfunding platform. It is also known as the first Islamic real estate crowdfunding platform in the world. Besides, EthisCrowd is known as the first ethical and Islamic real estate crowdfunding platform in the world.

In light of the review of the previous literature, there is a need to develop a crowdfunding model for the development of entrepreneurship in Malaysia. More specifically, it is foreseen that the equity crowdfunding model will benefit Muslim entrepreneurs with its risk-sharing element that is in line with the Shari ah. However, before that, a survey is undertaken to gauge Malaysian entrepreneurs' understanding of crowdfunding and their intention to use it. This is to justify the need to introduce an SEC framework.

\section{Entrepreneurs' intention to use crowdfunding in Malaysia}

A survey to assess the awareness of and experiences with, crowdfunding was undertaken to measure entrepreneurs' willingness to raise funds through this mechanism. This survey finding is important to justify the need to develop the conceptual SEC framework for Muslim investors in Malaysia. This survey will be able to address concerns raised by crowdfunding operators that most start-ups, micro-enterprises and small and medium enterprises (SMEs) are still not aware of raising funds through ECF or P2P. Focusing on the Klang Valley area, the survey conducted targeted entrepreneurs based on the random sampling method within different types of business areas. Questionnaires were distributed and the authors managed to collect data from 200 respondents, representing a sufficient number for quantitative analysis.

\section{Demographic information on entrepreneurs}

Table II provides descriptions of the entrepreneur sample collected in areas covering Kuala Lumpur and Selangor. Business activities include construction and provision of services, etc. Most of the entrepreneurs surveyed are sole proprietors with less than five years of business experience. In terms of turnover, half of them have annual sales turnover within the range of RM 10,000-RM 50,000, which categorizes them as SMEs.

The survey comprises questions on their knowledge of crowdfunding as a mechanism for raising funds. To measure their willingness to use it, several situations are presented for them to indicate their responses based on the five-point Likert scale, namely, strongly agree, agree, neutral, disagree and strongly disagree.

\section{Technology acceptance model}

Technology acceptance model (TAM) is a theoretical model that explains and predicts user behavior vis-à-vis information technology. It is an influential extension of the theory of reasoned action (TRA). Originally introduced by Davis (1989), TAM is a frequently used model that provides a foundation to trace how external variables influence belief, attitude and the intention to use a particular idea or framework. The theory is built based on the two cognitive beliefs of "perceived usefulness" (PU) and "perceived ease of use" (PEU). It posits that these beliefs are able to directly or indirectly influence users' behavioral intentions (BI) to actually use that idea or framework. TAM also suggests that intention and actual use can be affected by external factors through mediated effects on PU and PEU (Figure 1).

TRA has been extensively used by researchers to analyze the behavior of respondents regarding ideas or frameworks in various areas; for example, the intention to use cash waqf (Sakti et al., 2016), the intention to choose Islamic banking products (Abduh et al., 2011) or students' intention to choose ar-rahnu (Islamic pawnbroking) (Amin and Chong, 2013). 
Gender

Male

Female

244 Activity

Services

Ownership

Sole proprietorship

Partnership

Private limited

Business years

0-5 years

6-10 years

Sales turnover (RM)

Table II.

Description of entrepreneurs in Kuala Lumpur and Selangor
10,000-50,000

50,001-100,000

100,001-150,000

150,001-200,000

200,001-300,000

$>300,000$
Figure 1. TAM

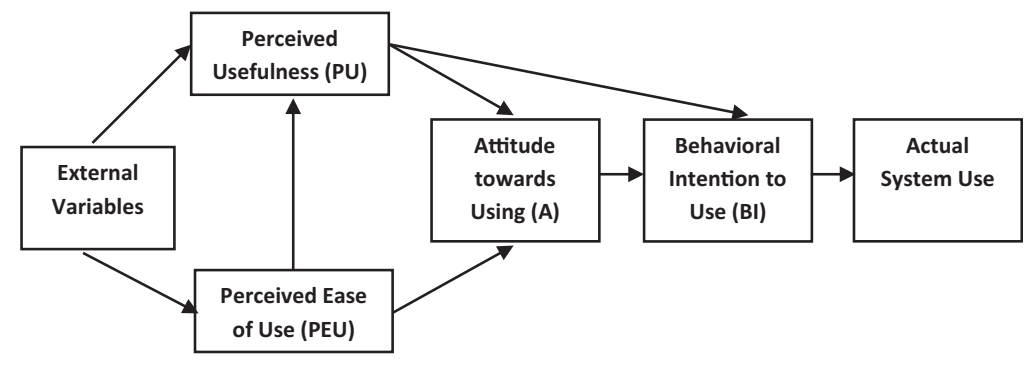

Source: Davis (1989)

Hence, in our study to measure the intention of entrepreneurs to use crowdfunding, we also base our analysis on the same theory.

As mentioned above, one of the important components of TAM is "PU". PU is defined as the degree to which an individual believes that using a proposed system or model would enhance his or her performance. In the case of crowdfunding, it is expected that crowdfunding will have a positive effect on the performance of entrepreneurs in raising funds for project financing. In addition to that, attitude can also be influenced by "PEU". If raising funds through crowdfunding is perceived to be easy, it would encourage more entrepreneurs to use it. Hence, crowdfunding is expected to have a positive impact on the 
behavior of entrepreneurs. As such, in this study two hypotheses are tested for measuring the willingness of entrepreneurs to use crowdfunding:

H1. There is a positive and significant relationship between PU and BI to use crowdfunding.

H2. There is a positive and significant relationship between PEU and BI to use crowdfunding.

\section{Methodology}

The statistical method used in testing the path model is SEM, a second-generation method of statistical analysis developed to analyze conceptual relationships, especially when dealing with latent constructs in a model. Two main advantages of using SEM are as follows: its ability to estimate multiple and interrelated dependence relationships and its ability to measure unobserved concepts in the model and to account for measurement error in the estimation techniques (Sakti et al., 2016). The latent constructs for this model are PU, PEU and BI. Each of these latent constructs is made up of items, which refer to the questions asked in the survey. To ensure that each item is relevant to the respective latent construct, a confirmatory factor analysis (CFA) needs to be undertaken. In this analysis, the validity and reliability of the constructs are affirmed when the factor loading of each item is more than 0.70 (Anderson and Gerbing, 1988).

Subsequently, to examine the possible causal link between statistical variables in SEM, we look at the path coefficients, which are the standardized versions of linear regression. They are obtained by multiplying the ordinary regression coefficient by the standard deviations of the corresponding explanatory variable. The values can then be compared to assess the relative effects of the variables within the fitted regression model.

\section{Research findings}

Before running the SEM, an initial measurement model is developed that incorporates three latent constructs indicated by the respective items pertaining to each scale, namely, PU, $\mathrm{PEU}$ and $\mathrm{BI}$.

To test the goodness of fit of the initial model, the Normed $\chi 2$ statistic should be more than the recommended level of 0.50 . One of the reasons for a poorly fit model could be due to the low factor loading of several items in the latent construct (below 0.70). If this happens, it is suggested that these items be deleted and the new measurement model then needs to be rerun. In our case, items $B I 2$ and $B I 3$ in the initial model were deleted as their factor loading was less than 0.70 . The final measurement model was then rerun and the result is presented in Figure 2 and Table III, which show a measurement model that is a reasonable fit for the data.

Table IV shows the final CFA for the final measurement model. The standardized factor loadings are observed to be fairly significant and high, ranging from 0.882 to 0.934 , which suggests a convergence of the indicators with the underlying factors (Anderson and Gerbing, 1988). in addition to that, the values for average variance extracted (AVE) for each construct are all above 0.50 (Fornell and Larcker, 1981). Hence, these results indicate reliable findings on the uni-dimensionality, reliability and validity of the measures

A structural model is then estimated to test the hypotheses of the study as shown in Figure 3 below. The statistics of the goodness of fit of the model indicate that it reasonably fits with the current data. The Chi-square value of the model $\left(\chi^{2}=76.24, \mathrm{~d} f=39, p=0.000\right)$ and some other goodness-of-fit indices (Normed $\chi^{2}=1.955$; root mean square error of
Crowdfunding framework 
IJIF

12,2

246

Figure 2.

Final measurement model

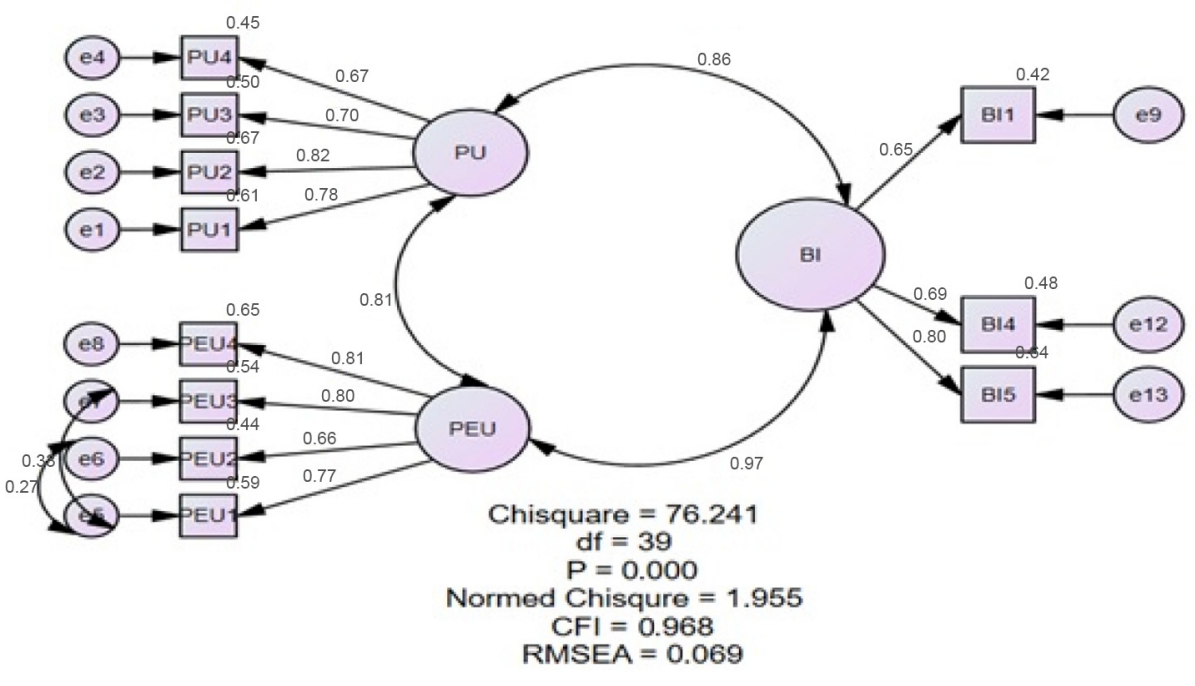

Source: Authors' own

Table III.

Final measurement model - fit indices

\begin{tabular}{lcccccl}
\hline Model & $\chi^{2}$ & df & Normed $\chi^{2}$ & RMSEA & CFI & Comment \\
\hline Final measurement model & 76.241 & 39 & 1.955 & 0.069 & 0.968 & $\begin{array}{l}\text { The required level is } \\
\text { achieved }\end{array}$
\end{tabular}

Table IV.

The CFA results for the measurement model

\begin{tabular}{llcccc}
\hline Construct & Items & Factor loading & Cronbach's alpha (above 0.7) & CR (above 0.6) & AVE (above 0.5) \\
\hline PU & & & 0.846 & 0.846 & 0.581 \\
& PU1 & 0.903 & & & \\
& PU2 & 0.911 & & & \\
& PU3 & 0.925 & 0.835 & 0.835 & 0.560 \\
PEU & PU4 & 0.923 & & & \\
& & & & & \\
& PEU1 & 0.904 & & 0.756 & 0.511 \\
& PEU2 & 0.924 & 0.756 & & \\
BE & PEU3 & 0.902 & & & \\
& PEU4 & 0.912 & & &
\end{tabular}

approximation $(\mathrm{RMSEA})=0.069$; comparative fit index $(\mathrm{CFI})=0.968)$ also show the fitness of the model.

The hypotheses are tested by examining the significance, signs and magnitude of the estimated coefficients (Hair et al., 2006). To examine the possible causal link between the statistical variables in SEM, path coefficients, which are the standardized versions of linear 


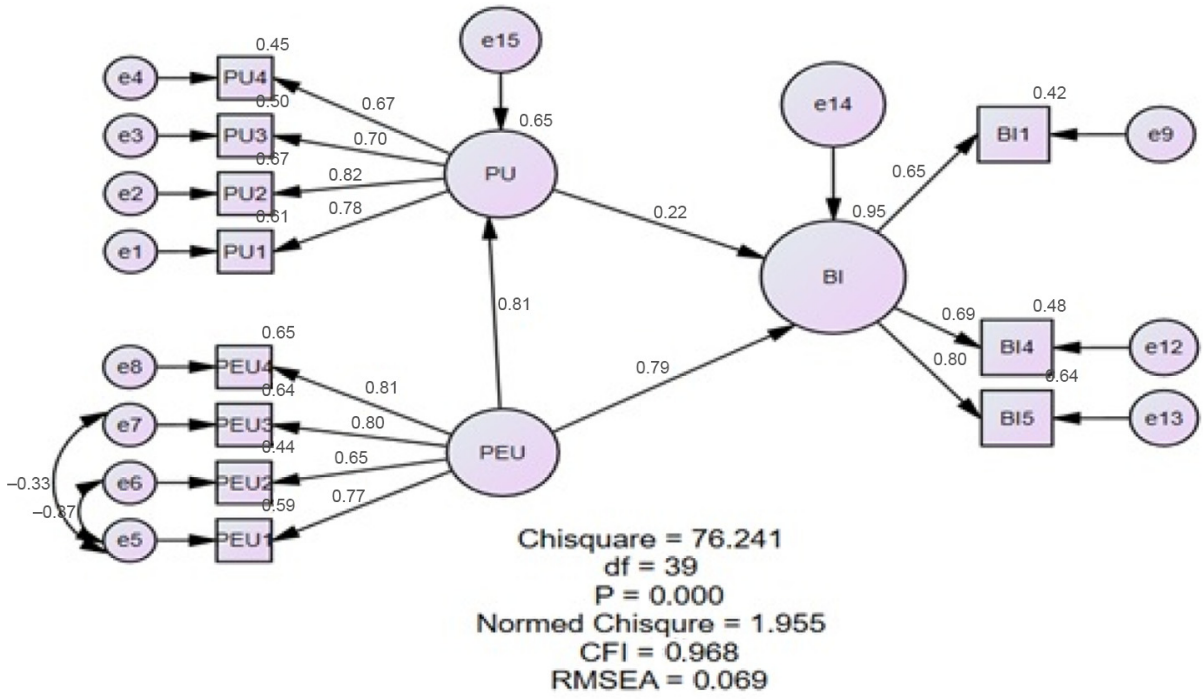

Source: Authors' own

regression, can be used. They can be obtained by multiplying the ordinary regression coefficient with the standard deviations of the corresponding explanatory variable. The values can then be compared to assess the relative effects of the variables within the fitted regression model.

As displayed in Table $\mathrm{V}$, the result of the relationship between $\mathrm{PU}$ and $\mathrm{BI}$ is not statistically significant $(\beta 1=0.182, t$-values $=1.897, p>0.01)$ and does not support the hypothesis. This could be interpreted as some of the entrepreneurs being quite cautious about sharing their business ideas online. This assessment is in line with the feedback from the crowdfunding platform operators in Malaysia that some entrepreneurs, especially those who lack information and computer technology skills, are quite reluctant to participate in crowdfunding (Rahman et al., 2016).

Nonetheless, the result of the relationship between PEU and BI is statistically significant $(\beta 1=0.667, t$-values $=5.542, p<0.01)$, which supports the research hypothesis. The standardized coefficient result indicates that if PEU goes up by one standard deviation, BI goes up by 0.667 standard deviations. As such, it is perceived that the entrepreneurs do agree on the ease of use of crowdfunding in meeting their capital needs, given the dedicated support offered by the crowdfunding platforms.

\begin{tabular}{|c|c|c|c|c|}
\hline Hypothesized path & Standardized coefficient & $t$-value & $p$-value & Decision \\
\hline $\mathrm{PU} \rightarrow \mathrm{BI}$ & 0.182 & 1.897 & 0.058 & PU and BI are not significant \\
\hline $\mathrm{PEU} \rightarrow \mathrm{BI}$ & 0.667 & $5.542^{*}$ & 0.000 & $\begin{array}{l}\mathrm{PEU} \text { and BI are significant and } \\
\text { positively related }\end{array}$ \\
\hline
\end{tabular}

Note: $* p$-value $<0.01$
Crowdfunding framework

Figure 3. Structural model
Table V. Results of hypothesis testing 
Even though one of the hypotheses tested is not significant, it is generally deduced that crowdfunding is still perceived to be useful for Malaysian entrepreneurs, particularly because of the rapid growth of equity crowdfunding and P2P lending locally. Hence, with that in mind, to offer a better alternate for Muslim entrepreneurs, in particular, an SEC framework is proposed in the following section that incorporates crowdfunding qualities blended with Sharī'ah requirements and current practices.

\section{8}

\section{En route to Sharī'ah-compliant crowdfunding}

Islamic finance promotes alternate financing that is supported by ethical and socially accountable standards, emphasizing the just distribution of benefits and obligations among all parties involved in the financial transactions. Generally, crowdfunding exemplifies these features as it requires all information related to the entrepreneurs (fundraisers) to be disclosed to the investors (funders) and close connections are built between them through the updates and project progress reports once funding has been secured. The mechanism of equity-based crowdfunding, which is similar to a partnership arrangement, is seen as a positive step forward for crowdfunding in the Muslim world.

It is also important to highlight that the hatal market is estimated to be more than US $\$ 2.2 \mathrm{tn}$ a year, with over 1.6 billion Muslims across the world and it is expected to increase exponentially in line with the growing numbers of Muslim population around the world (Thomson Reuters, 2019). Apart from Shekra, another well-known equity crowdfunding platform is Kapital Boost, which offers a financing facility known as SME crowdfunding. Kapital Boost predominantly uses two Sharī'ah contracts: murābahah (cost-plus sale) and mudà rabah (silent-partner partnership). While the murābahah arrangement is more suitable for start-up entrepreneurs, the mudärabah contract suits projects, which have good clarifications in terms of costs and revenue.

\section{Developing a Sharī ah-compliant equity crowdfunding framework for Malaysian entrepreneurs}

By analyzing the current equity-based crowdfunding stages and procedures, a conceptual SEC framework is developed that involves three main phases as follows: the pre-funding phase, funding phase and post-funding phase. Figure 4 below presents a proposed SEC framework during the pre-funding and funding phases with the following detailed modus operandi:

- Entrepreneurs who wish to raise funds through SEC will need to establish a relationship with a dedicated equity-based crowdfunding platform operator. It is suggested that their relationship be based on the wakalah (agency) contract, as the platform will be acting as an agent or middleman for the entrepreneur in fundraising activities.

- Upon registering with an approved equity-based crowdfunding platform, the entrepreneurs will undergo an assessment process, which is standard practice in the crowdfunding industry. This will involve the screening process, due diligence and Sharī'ah-compliance assessment. In the proposed framework, Sharīah compliance is proposed to be undertaken by two parties, namely the equity-based crowdfunding platform, as well as an independent Shari' ${ }^{-}$ah advisor, to ensure that the business and fundraising causes are in line with the Shari' ${ }^{-}$ah. This follows the current practice of equity-based crowdfunding whereby the regulator, Securities Commission Malaysia, oversees the conduct of fundraising together with the platforms. If the assessment process gets approved, it will proceed to the funding phase (2A in Figure 4). Otherwise, 


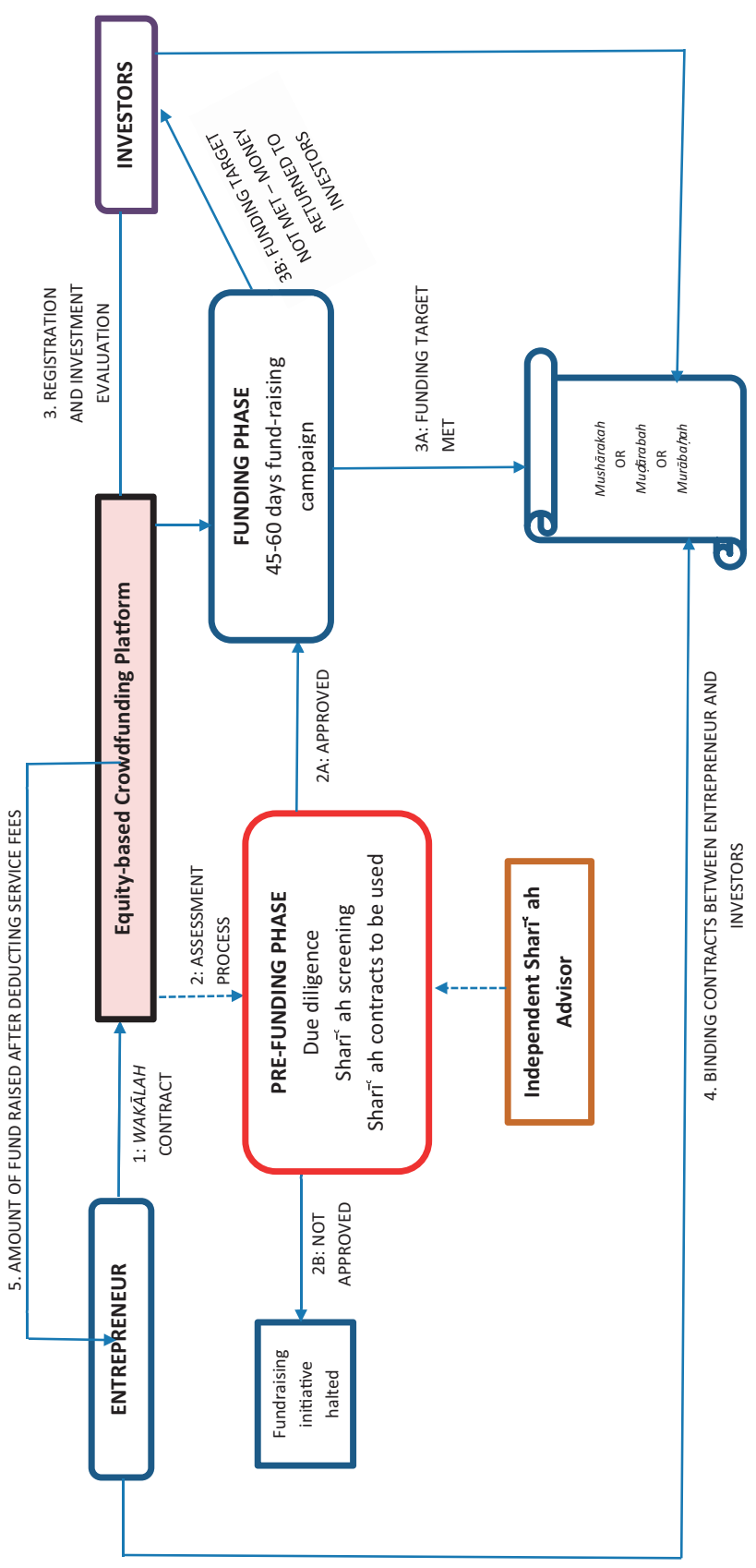

Crowdfunding framework

Figure 4. Proposed SEC framework - prefunding and funding phases 
$\mathrm{IJIF}$

12,2

250

Figure 5.

Proposed SEC framework - postfunding the whole fundraising initiative will be halted (2B). It is important to highlight that it is at this stage that appropriate contracts are decided for the entrepreneur to use to raise the funding target. The proposed contracts could be in the form of muräbahah, mushärakah or mud̄arabah. For each of these contracts, there are some specific elements, which should be made transparent; for example, if murābahah contract is used, the cost and profit must be clearly disclosed.

- Once the projects are made available on the equity-based crowdfunding platform, investors can start registering themselves and evaluating the projects for the purpose of investment. It is very important to emphasize that at this stage, the equity stake, potential return, exit strategies and other benefits to be obtained by the investors are to be clearly spelled out. Progress and updates throughout the funding period, which normally ranges from 45 to 60 days, must also be made available on the SEC platform. During this stage, it is important for the entrepreneurs to keep updating the potential investors on the relevant information such as the amount of funding secured and the balance of days remaining to make an investment. Face-to-face meetings may also be arranged with investors. Should the project meet the investors' appetite, they can commit their monies through the platform, which is normally done via the online payment mechanism (including PayPal). This proposed framework proposes the "All or Nothing" concept, whereby the contract will be executed if the fund target is met (3A); otherwise, the investors' money will be returned (3B).

- When the funding phase is concluded and the funding target has been achieved (3A), all the necessary and legal documents must be produced such as the shareholder agreements, which clearly spell out the obligations of the entrepreneurs to their investors. A binding Sharī'ah contract between the entrepreneur and investors (mushārakah, mud̄arabah or murābahah, as proposed earlier in the prefunding stage) will stipulate all the details relevant to the invested project.

- The collected funds will then be transferred from the equity-based crowdfunding platform to the entrepreneurs, after deducting all related fees.

It is important to emphasize that the relationship established between the entrepreneurs and investors continues to be nourished and strengthened via periodic updates, board presentations, milestones of financing and so forth, which are categorized as the post-funding phase. This information can be published via the equity-based crowdfunding platform or the entrepreneurs'

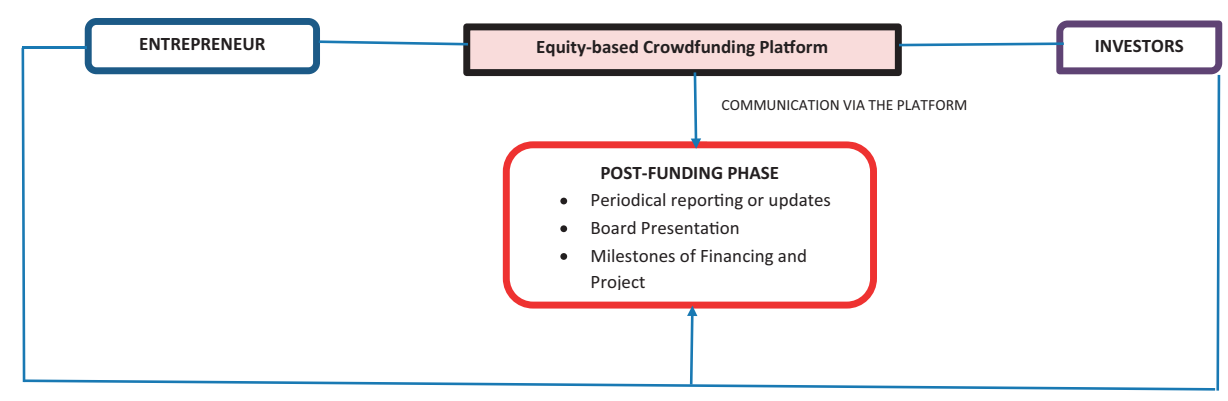

DIRECT COMMUNICATION VIA COMPANY WEBSITES

Source: Authors' Own 
own websites as shown in Figure 5. Nonetheless, it is noticed that communication between the entrepreneurs and investors is done via the crowdfunding platform.

It is expected that by going through these three phases meticulously, the objectives of entrepreneurs to raise funds via an alternate Shari' ${ }^{-1}$ ah-compliant mechanism such as SEC can be achieved. Most importantly, this could also be an additional funding mechanism that could strengthen the financial ecosystem, particularly in Malaysia.

\section{Conclusion and recommendation}

This paper evaluates the concept of crowdfunding and how it could benefit Muslim entrepreneurs, particularly in Malaysia. With the emergence of many equity crowdfunding platforms, this paper examines the current crowdfunding platforms and highlights the Sharīah contracts mainly used in the effort to develop an SEC framework for Malaysia. The identification of issues related to crowdfunding has led to introducing an SEC framework for an alternate method of financing.

Nonetheless, before developing a conceptual SEC framework for use by entrepreneurs, their general understanding of crowdfunding and their willingness (or intention) to use it have been assessed. To that end, a survey sample of local entrepreneurs in Malaysia has been undertaken and analyzed based on the extended TRA, which is TAM, through the use of SEM.

This paper makes two main contributions to the existing literature. First, it provides evidence on Malaysian entrepreneurs' intention to use crowdfunding for their fundraising exercise through TRA and TAM by applying the method of SEM accordingly. Second, it proposes a conceptual SEC framework for the development of entrepreneurship in Malaysia.

For future research, there is a plan to share the proposed SEC framework with stakeholders to obtain feedback for further improvement. Apart from that, additional analysis can also be undertaken by extending the proposed framework outside Malaysia; for example, Indonesia and Singapore. It is an aspiration for this framework to become the standard operating procedure on the offering of SEC not only to entrepreneurs in Malaysia but also to the rest of the world.

\section{References}

Abduh, M., Duasa, J. and Omar, M.A. (2011), "Factors influence depositors' withdrawal behavior in Islamic banks: a theory of reasoned action”, World Academy of Science, Engineering and Technology, Vol. 60, pp. 2074-2079.

Achsien, I.H. and Purnamasari, D.L. (2016), "Islamic crowd-funding as the next financial innovation in Islamic finance: potential and anticipated regulation in Indonesia", European Journal of Islamic Finance, Vol. 5, pp. 1-10.

Alonso, I.M. (2015), "Crowdfunding in Islamic finance and microfinance: a case study of Egypt. Access to finance and human development", Essays on Zakah, Awqaf and Microfinance, pp. 85.

Amin, H. and Chong, R. (2013), "Determinants for ar-rahnu usage intentions: an empirical investigation", African Journal of Business Management, Vol. 5 No. 20, pp. 8181-8191.

Anderson, J.C. and Gerbing, D.W. (1988), "Structural equation modeling in practice: a review and recommended two-step approach", Psychological Bulletin, Vol. 103 No. 3, pp. 411-423.

Davis, F.D. (1989), "Perceived usefulness, perceived ease of use, and user acceptance of information technology”, MIS Quarterly, Vol. 13 No. 3, pp. 319-340.

Ferrary, M. and Granovetter, M. (2009), "The role of venture capital firms in Silicon valley's complex innovation network", Economy and Society, Vol. 38 No. 2, pp. 326-359.

Fornell, C. and Larcker, D.F. (1981), "Structural equation models with unobservable variables and measurement error: algebra and statistics", Journal of Marketing Research, Vol. 18 No. 3, pp. 382-388.
Crowdfunding framework 
$\mathrm{IJIF}$

12,2

Fundly (2020), "Crowdfunding statistics", available at: https://blog.fundly.com/crowdfundingstatistics/ (accessed 25 May 2020).

Gerber, E.M., Hui, J.S. and Kuo, P.Y. (2012), "Crowdfunding: why people are motivated to post and fund projects on crowdfunding platforms", Proceedings of the International Workshop on Design, Influence, and Social Technologies: Techniques, Impacts and Ethics, Vol. 2, ACM, New York, NY.

Hair, J.F., Black, W.C., Babin, B.J., Anderson, R.E. and Tatham, R.L. (2006), Multivariate Data Analysis, Vol. 6, Prentice-Hall, Upper Saddle River, NJ.

Hoegen, A. Steininger, D.M. and Veit, D. (2017), "How do investors decide? An interdisciplinary review of decision-making in crowdfunding", available at: https://doi.org/10.1007/s12525-017-0269-y (accessed 8 June 2020).

Massolution, C.L. (2015), "Crowdfunding industry report", available at: http://reports.crowdsourcing. org/index.php (accessed 25 July 2018).

Rahman, M.P., Duasa, J., Kamil, M. and Kamil, N. (2016), "Factors contributing to the success of crowdfunding: the Malaysian case", paper presented at the Asia-Pacific Conference on Economics and Finance (APEF), 27-28 July, Singapore.

Sakti, M.R.P., Thaker, H.B.M.T., Qoyum, A. and Qizam, I. (2016), "Determinants of cash waqf contribution in Klang Valley and Selangor: an SEM approach", Journal of Islamic Monetary Economics and Finance, Vol. 2 No. 1, pp. 111-144.

Securities Commission Malaysia (2020), "Crowdfunding statistics", available at: www.sc.com.my (accessed 8 June 2020).

Statista (2020), "Market size of crowdfunding worldwide in 2018 and 2025 (in billion U.S. dollars)", available at: www.statista.com/statistics/1078273/global-crowdfunding-market-size/ (accessed 8 June 2020).

Thomson Reuters (2019), "State of the global Islamic economy report 2019/20", available at: www. salaamgateway.com/SGIE19-20 (accessed 8 June 2020).

Valanciene, L. and Jegeleviciute, S. (2013), "Valuation of crowdfunding: benefits and drawbacks", Economics and Management, Vol. 18 No. 1, pp. 39-48.

Wahjono, S.I. and Marina, A. (2015), "Islamic crowdfunding: alternative funding solution", paper presented at the 1st World Islamic Social Science Congress (WISSC 2015), 1-2 December, Putrajaya.

World Bank (2013), “Crowdfunding's potential for the developing world”, available at: www.infodev. org/infodev-files/wb_crowdfundingreport-v12.pdf (accessed 1 July 2018).

\section{About the authors}

Maya Puspa Rahman, $\mathrm{PhD}$, is an Associate Professor at the Department of Economics, Faculty of Economics and Management Sciences, International Islamic University Malaysia (IIUM), Malaysia. She has more than 10 years of industrial experience in various financial sectors including takâful, asset management and stockbroking. Her research areas include șukuk, crowdfunding, complementary currencies and structured products. Maya Puspa Rahman is the corresponding author and can be contacted at:mayapuspa@iium.edu.my

Mohamed Asmy Mohd Thas Thaker, $\mathrm{PhD}$, is currently an Associate Professor at the Department of Economics, Faculty of Economics and Management Sciences, IIUM, Malaysia. His areas of specialization are Islamic economics and Islamic banking and finance.

Jarita Duasa, PhD, is a Professor at the Department of Economics, Faculty of Economics and Management Sciences, IIUM, Malaysia. Her research niche areas are International Economics, International Finance and Applied Economics.

For instructions on how to order reprints of this article, please visit our website:

www.emeraldgrouppublishing.com/licensing/reprints.htm

Or contact us for further details: permissions@emeraldinsight.com 